
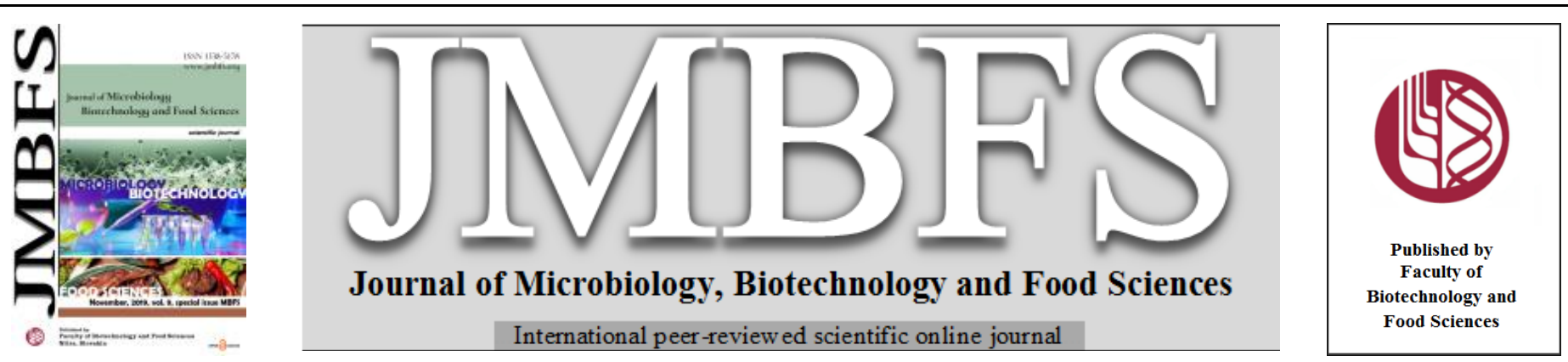

\title{
THE EFFECT OF MURAMYL DIPEPTIDE AND LIPOPOLYSACCHARIDE ON EXPRESSION OF CD14 AND CD44 BY BOVINE MAMMARY GLAND NEUTROPHILS IN VITRO
}

\author{
Terezie Zavadilova *, Zbysek Sladek, Lucie Kratochvilova, Petr Slama, Dusan Rysanek
}

Address(es): Ing. Terezie Zavadilová, Ph.D.,

Mendel University in Brno, Faculty of AgriSciences, Zemědělská 1, 61300 Brno, Czech Republic

*Corresponding author: zavadilova.terezie@gmail.com

doi: 10.15414/jmbfs.2019.9.special.467-472

\section{ARTICLE INFO}

Received 7. 7. 2019

Revised 18. 10. 2019

Accepted 22. 10. 2019

Published 8. 11. 2019

Regular article

OPEN $\partial_{\text {AcCESS }}$

\begin{abstract}
Previous studies indicate neutrophils' expression of CD14 and CD44 is associated with stage of inflammatory response. This study, undertaken in vitro investigates whether bacterial components affect neutrophils' CD14 and CD44 expression and lifespan. Neutrophils, obtained through lavage of mammary glands, were incubated with three different concentrations of muramyl dipeptide (MDP) and lipopolysaccharide (LPS). Percentages of apoptotic neutrophils, and of CD14+ and CD44+ neutrophils, were detected after 30, 60, 120 and 300 minutes of incubation. A high concentration of MDP produced a significantly higher percentage of CD14+ after 30 and 120 minutes, compared with LPS and the control, for which percentages remained constant. CD44+ increased at low concentrations of MDP and LPS after 120 minutes, and at 60 minutes for intermediate concentrations. High concentrations resulted in significant increase, this after only 30 minutes for MDP. Analysis of variance indicated incubation time followed by bacterial component, as most important in expression of CD14 and CD44.
\end{abstract}

\section{INTRODUCTION}

The function of neutrophils is to eliminate pathogenic microorganisms during the initial phase of acute inflammation, the point at which migration of these cells from blood to the affected tissue occurs. Lipopolysaccharide (LPS), a component of Gram-negative bacteria's cellular wall, and muramyl dipeptide (MDP), a minimal structural unit of peptidoglycan in Gram-positive and Gram-negative bacteria, have the ability to induce an inflammatory response (Sládek, Ryšánek, 2000; Ryšánek et al., 2001; Sládek et al., 2002).

The immune system can recognize these molecules by means of two types of "toll-like" receptors (TLR). TLR2 recognises Gram-positive bacterial components (peptidoglycan) whilst TLR4 recognises LPS, the component of Gram-negative bacteria (Takeuchi et al., 2000).

TLR4 plays a crucial role in the recognition of invading pathogens. Upon activation by LPS, TLR4 is recruited into specific membrane domains (Neumann et al., 2019).

Both structural components have an affinity to CD14. CD14 is expressed mainly by macrophages and by neutrophils. It is also expressed by dendritic cells. CD14 acts as a co-receptor (along with TLR 4) for the detection of bacterial lipopolysaccharide (LPS) (Kitchens, 2000; Tapping, Tobias, 2000). CD14 can bind LPS only in the presence of lipopolysaccharide-binding protein (LBP). Although LPS is considered its main ligand, CD14 also recognizes other pathogen-associated molecular patterns such as lipoteichoic acid (Ranoa et al., 2013).

Neutrophils are a type of phagocyte and are normally found in the bloodstream. During the beginning (acute) phase of inflammation, particularly as a result of bacterial infection, environmental exposure (Jacobs et al., 2010) neutrophils are one of the first-responders of inflammatory cells to migrate towards the site of inflammation. They migrate through the blood vessels, then through interstitial tissue, following chemical signals such as interleukin-8 (IL8), C5a, fMLP, leukotriene $\mathrm{B} 4$ and $\mathrm{H}_{2} \mathrm{O}_{2}$ (Yoo et al., 2011) in a process called chemotaxis.

Inflammation is a complex set of interactions among soluble factors and cells that can arise in any tissue in response to traumatic, infectious, post-ischaemic, toxic or autoimmune injury. The process normally leads to recovery from infection and to healing. However, if targeted destruction and assisted repair are not properly phased, inflammation can lead to persistent tissue damage by leukocytes, lymphocytes or collagen (Nathan, 2002). The inflammatory response is an integral part of the innate immune mechanism that is triggered in response to a real or perceived threat to tissue homeostasis, with a primary aim of neutralizing infectious agents and initiating repair to damaged tissue. Resolution of inflammation involves apoptosis and subsequent clearance of activated inflammatory cells - a tightly regulated event (Maskrey et al., 2011).

During spontaneous resolution, neutrophils undergo apoptosis, a highly regulated cell death mechanism that prevents the release of histotoxic cellular contents (Savill, 1989).

The first step in the elimination of apoptotic neutrophils is their identification by macrophages. Macrophages play important roles in the clearance of dying and dead cells, they are viewed as the professional phagocytes of apoptotic cells (Gregory, Devitt, 2004). Translocation of molecules from intracellular to extracellular sites is a proven mechanism whereby cells that have engaged their apoptosis programme can become rapidly visible to phagocytes. Exposure of phosphatidylserine on the apoptotic cell (Fadok $\boldsymbol{e t}$ al., 2001) and, at least in certain circumstances, its subsequent oxidation (Kagan $\boldsymbol{e t}$ al., 2002) appears to be a necessary prerequisite for clearance. Macrophages then have specific receptors with the ability to recognise apoptotic neutrophils (Savill et al., 1993). CD14 has been implicated in the clearance of apoptotic cells by macrophages. During the study of CD14's role in an inflammatory response within the heifer mammary gland, active participation of CD14 during resolution was considered. The role of the membrane receptor CD14 has previously been studied in mastitis induced in heifer mammary glands by LPS, Staphylococcus aureus and Streptococcus uberis. Paape et al. (1996) and Sládek et al., (2002) had found that the inflammatory response of the mammary gland to LPS was associated with an expression of CD14 receptors by neutrophils and macrophages, whereas expression of CD14 receptors greatly depends on the stage of the inflammatory response within the mammary gland. It has also been found that expression of CD14 on neutrophils correlates highly with the presence of apoptotic neutrophils (Sládek, Ryšánek, 2006)

Association of LPS with LBP and the subsequent creation of CD14-TLR-4 (Takeuchi et al., 1999) could result in an induction of CD44 expression. Ligation of human macrophage surface CD44 by bivalent monoclonal antibodies rapidly and profoundly augments the capacity of macrophages to phagocytose apoptotic neutrophils in vitro. Elevated local concentrations of CD44 ligands (such as hyaluronan and fibronectin) that follow tissue injury are likely to be important mediators of macrophage function as the inflammatory response progresses (Vivers et al., 2002). Khan et al. (2004) investigated, that neutrophils express CD44, and explained the role of CD44 and hyaluronan in the multistep process of neutrophil recruitment. CD44 can mediate some neutrophil adhesion and 
emigration but it does not seem to affect subsequent migration within tissues. Teder et al. (2002) observed that the cell-surface adhesion molecule and hyaluronan receptor CD44 plays a critical role in resolving lung inflammation. Vachon et al. (2006) determined that CD44 mediates efficient phagocytosis in primary murine peritoneal macrophages.

The results of previous studies have shown that expression of CD14 and CD44 is associated with the stage of inflammatory response. The question then arises as to whether bacterial components which induce the response also affect expression.

The purpose of the present study, therefore, was to investigate whether the cell wall components of Gram-positive and Gram-negative bacteria directly influence CD14 and CD44 expression on neutrophils.

\section{MATERIAL AND METHODS}

\section{Experimental animals and design}

The experiment was performed on three clinically normal heifers of HolsteinCzech Spotted cross, aged 15-18 months. These were housed in an accredited experimental animal facility and fed a standard diet consisting of hay and feed supplements. A bacteriological examination of the mammary glands of the experimental animals was performed before the beginning of each experiment. Only animals with negative bacteriological test results were used in the experiments.

Phosphate buffered saline (PBS, Sigma, Saint Louis, Mo., USA; 0.01 M, pH 7.4) was used to induce the inflammatory response in the mammary glands. The mammary glands were flushed with PBS, and cell suspensions were prepared for assessing total leukocyte counts and analysing the lifespan of neutrophils by light microscopy. The flow cytometry method (FCM) was used for detecting apoptotic neutrophils and analysing of neutrophil cell surface expression of CD14 and CD44.

\section{Induction of inflammatory response}

Approximately $20 \mathrm{ml}$ of PBS per mammary gland was used to induce inflammatory response. Mammary gland lavage was performed on the day of experiment. Induction of inflammatory response and lavage of mammary glands were performed by means of modified urethral catheters (AC5306CH06, Porges S. A., France) after disinfection with $70 \%$ ethanol.

\section{Processing of cell suspensions}

The lavage fluids obtained were evaluated by observation immediately after collection and samples were then taken for bacteriological examination and to assess total cell count and cell viability. Bacteriological examination was performed through culture on blood agar with $5 \%$ washed ram erythrocytes and aerobic culture at $37^{\circ} \mathrm{C}$ for 24 hours. Only the results of lavage samples that were negative in bacteriological culture were used in statistical processing.

The total number of cells was enumerated using a haemocytometer. The viability of cells from heifer mammary glands was assessed using the trypan blue exclusion method. The viability of cells was always higher than $97 \%$. The cell suspensions were then centrifuged for $10 \mathrm{~min}$. at $200 \mathrm{~g}$ and $4{ }^{\circ} \mathrm{C}$. The cell pellet was resuspended in $1 \mathrm{ml}$ of supernatant. The cells were adjusted to $2 \times 10^{6} / \mathrm{ml}$ in RPMI 1640 medium (Sigma, St. Louis, MO, USA).

\section{Culture of neutrophils with MDP and LPS in vitro}

Solutions of MDP were prepared in RPMI 1640 supplemented with BSA at concentrations of $2.0 \mu \mathrm{g} / \mathrm{ml}, 20.0 \mu \mathrm{g} / \mathrm{ml}$ and $200.0 \mu \mathrm{g} / \mathrm{ml}$. Similarly solutions of LPS were prepared in RPMI 1640 supplemented with BSA at concentrations of $0.2 \mu \mathrm{g} / \mathrm{ml}, 2.0 \mu \mathrm{g} / \mathrm{ml}$ and $20.0 \mu \mathrm{g} / \mathrm{ml}$. The wells of Corning plates were filled with cells suspended in medium containing appropriate concentrations of MDP and LPS. The cells were cultured in the Corning plates for 30,60, 120 and 300 min. at $38^{\circ} \mathrm{C}$ in $5 \% \mathrm{CO}_{2}$. A different Corning plate was filled for each term. After removal from the incubator, the cultures were centrifuged (10 min., $200 \mathrm{~g}$ ), resuspended in 1,100 $\mu \mathrm{l}$ RPMI 1640, and staining and analysis by FCM were undertaken.

\section{Detection of apoptosis}

Apoptotic neutrophils were determined by FCM, detected using two different biochemical markers for apoptosis:

i) Staining with Annexin V labeled with fluorescein isothiocyanate (FITC) and propidium iodide (PI) (Vermes et al., 1995; Lakshmanan, Batra, 2013). The Annexin-V-FLUOS Staining Kit (Boehringer Mannheim, Mannheim, Germany) was used for staining in accordance with the manufacture's instructions.

ii) Staining with commercial SYTO 13 green fluorescent nucleic acid stain (Molecular Probes, Eugene, Oregon, USA) was used as described by Dosogne et al. (2003), with a slight modification, i.e. $490 \mu \mathrm{l}$ of cell suspension in RPMI 1640 was stained with $10 \mu 1$ of diluted (1:40) SYTO 13 solution.

\section{Detection of surface receptors}

Mouse anti-ovine CD14 VPM65 (Serotec, Oxford, UK) diluted 1:20 and fluorescein isothiocyanate-labeled goat anti-mouse IgG1-R-PE (SouthernBiotech, Birmingham, Alabama, USA) diluted 1:500 were used as the primary and secondary antibodies, respectively. Negative control samples were stained with the secondary antibody only.

Mouse anti-ovine antibody CD44 BAG40A (VMRD Inc. Pullman, Washington, USA) diluted 1:50 and FITC labeled IgG3 (SouthernBiotech, Birmingham, USA) diluted 1:100 diluted 1:100 were used as the primary and secondary antibodies, respectively.

For analysis, the FACSCalibur flow cytometer and CELLQuest ${ }^{\mathrm{TM}}$ software (Becton Dickinson, Mountain View, California, USA) were used. The dot plots obtained were subsequently evaluated using WinMDI 2.8 software (Trotter, 2000). A 20,000 PMN/dot plot was always analysed.

\section{Statistics}

The data obtained were statistically processed using the Statistica $7.1 \mathrm{CZ}$ program (StatSoft CZ, Czech Republic). The differences in percentages of apoptotic, CD14+ and CD44+ neutrophils were statistically evaluated using the ANOVA test for analysis of variance.

\section{RESULTS}

Effect of MDP and LPS on the percentage of apoptotic neutrophils during incubation

Figures 1, 2 and 3 show the percentages of apoptotic neutrophils during incubation with different concentrations of MDP and LPS after staining with Annexin V/PI. Significant differences between PBS and MDP $(20.0 \mu \mathrm{g} / \mathrm{ml}$, $\mathrm{p}<0.001)$, PBS and LPS $(2.0 \mu \mathrm{g} / \mathrm{ml}, \mathrm{p}<0.01)$ and PBS and MDP $(200.0 \mu \mathrm{g} / \mathrm{ml}$ $\mathrm{p}<0.05)$ were detected after 300 min incubation.

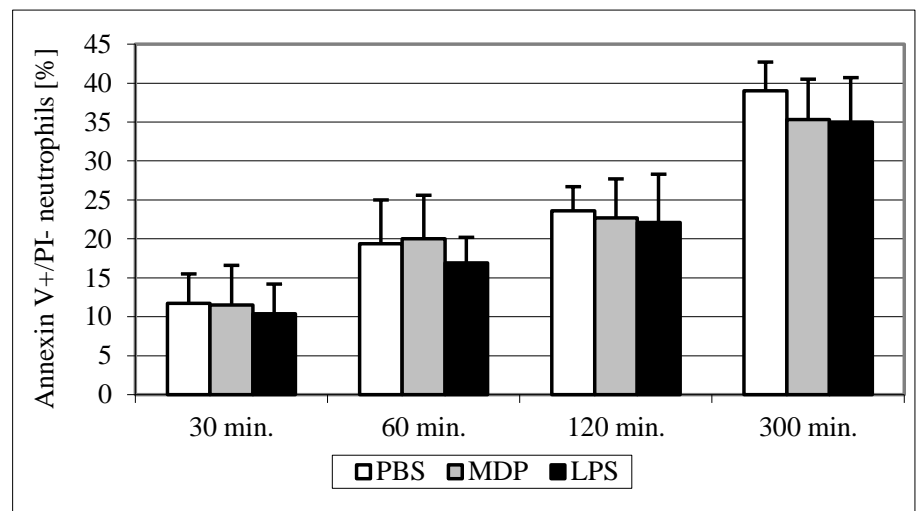

Figure 1 Proportion of Annexin V+/PI- neutrophils MDP $2.0 \mu \mathrm{g} / \mathrm{ml}$, LPS 0.2 $\mu \mathrm{g} / \mathrm{ml}$

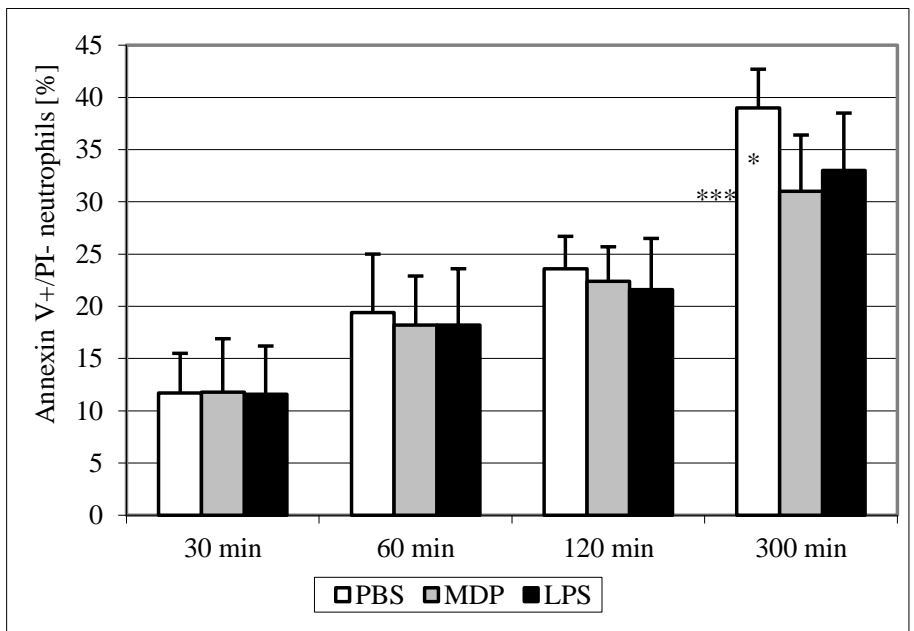

Figure 2 Proportion of Annexin V+/PI- neutrophils MDP 20,0 $\mu \mathrm{g} \cdot \mathrm{ml}^{-1}$, LPS 2,0 $\mu \mathrm{g} . \mathrm{ml}^{-1}$ 


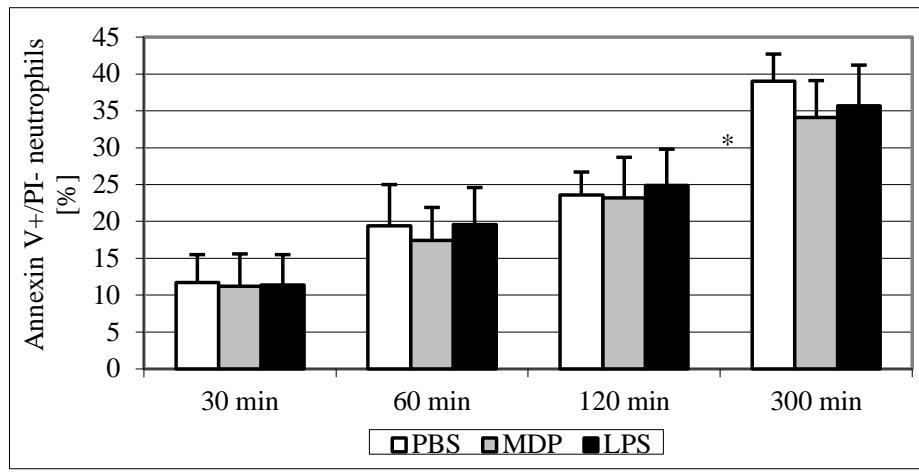

Figure 3 Proportion of Annexin V+/PI- neutrophils MDP 200,0 $\mu \mathrm{g} \cdot \mathrm{ml}^{-1}$, LPS $20,0 \mu \mathrm{g} \cdot \mathrm{ml}^{-1}$

Apoptotic neutrophils were detected by staining with both Annexin V/PI and SYTO13. Their percentages are presented in Figures 4, 5 and 6. Significant differences between PBS and MDP $(20.0 \mu \mathrm{g} / \mathrm{ml}, \mathrm{p}<0.05)$, and between PBS and LPS $(2.0 \mu \mathrm{g} / \mathrm{ml}, \mathrm{p}<0.05)$ were detected after $120 \mathrm{~min}$ incubation. Significant differences between PBS and all three concentrations of MDP ( $<<0.05)$, and between PBS and LPS $(0.2 \mu \mathrm{g} / \mathrm{ml}, \mathrm{p}<0.01)$, were detected after $300 \mathrm{~min}$ incubation.

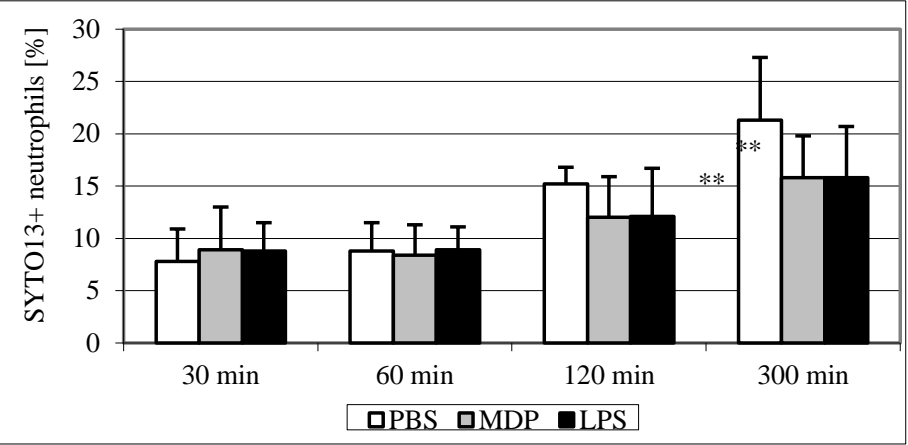

Figure 4 Proportion of apoptotic neutrophils - SYTO 13 MDP 2,0 $\mu$ g.ml ${ }^{-1}$, LPS $0,2 \mu \mathrm{g} \cdot \mathrm{ml}^{-1}$

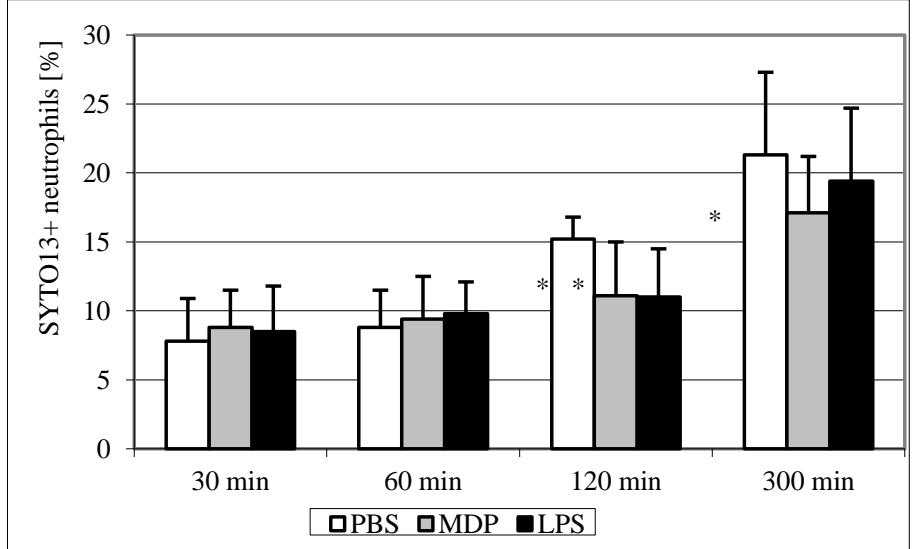

Figure 5 Proportion of apoptotic neutrophils - SYTO 13 MDP 20,0 $\mu \mathrm{g} \cdot \mathrm{ml}^{-1}$, LPS $2,0 \mu \mathrm{g} \cdot \mathrm{ml}^{-1}$

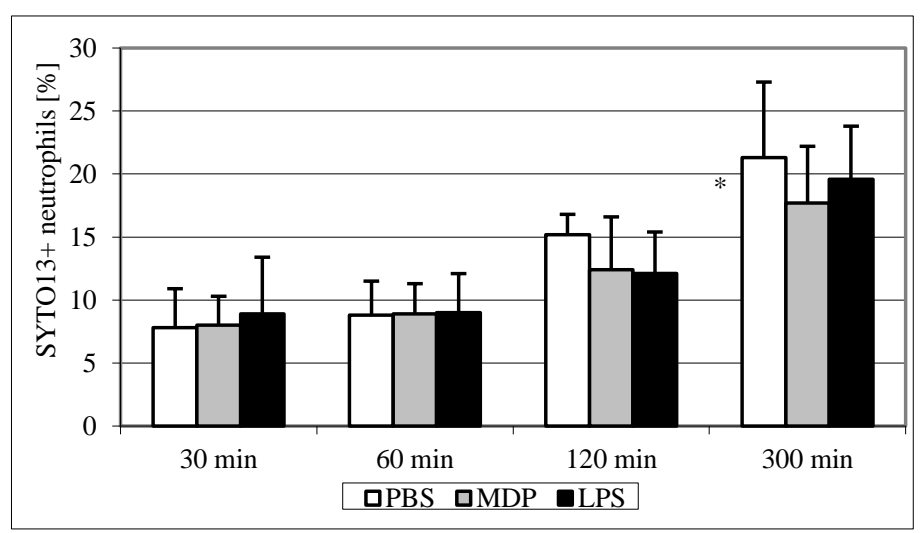

Figure 6 Proportion of apoptotic neutrophils - SYTO 13 MDP 200,0 $\mu \mathrm{g} . \mathrm{ml}^{-1}$, LPS $20,0 \mu \mathrm{g} \cdot \mathrm{ml}^{-1}$
The effect of MDP and LPS on percentages of CD14+ and CD44+ neutrophils during incubation

The percentages of CD14+ neutrophils after incubation with different concentrations of MDP and LPS at different time periods are presented in Figures 7,8 and 9 . When compared to PBS, a significantly higher percentage was only detected in MDP $(200.0 \mu \mathrm{g} / \mathrm{ml})$ after the $30(\mathrm{p}<0.01)$ and $120 \mathrm{~min}(\mathrm{p}<0.05)$ incubations.

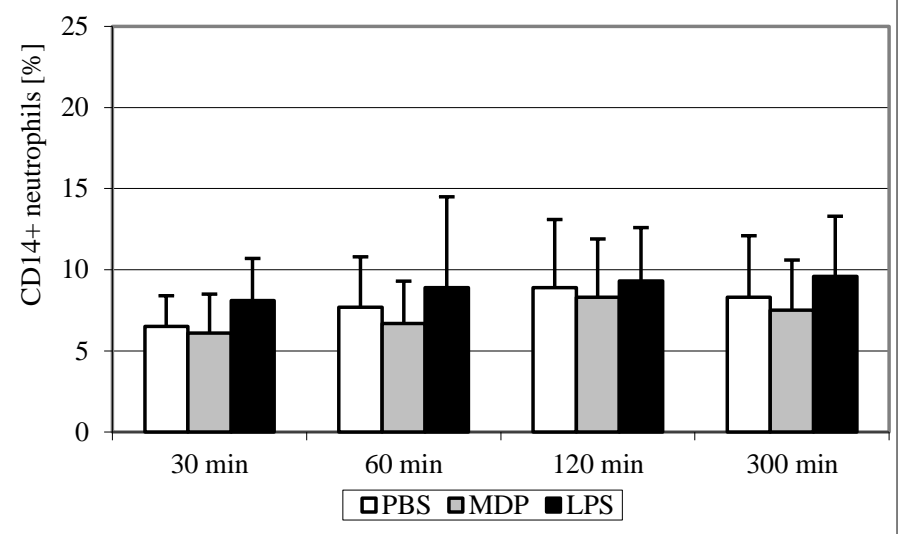

Figure 7 Proportion of CD14+ neutrophils MDP 2,0 $\mu \mathrm{g} \cdot \mathrm{ml}^{-1}$, LPS $0,2 \mu \mathrm{g} \cdot \mathrm{ml}^{-1}$

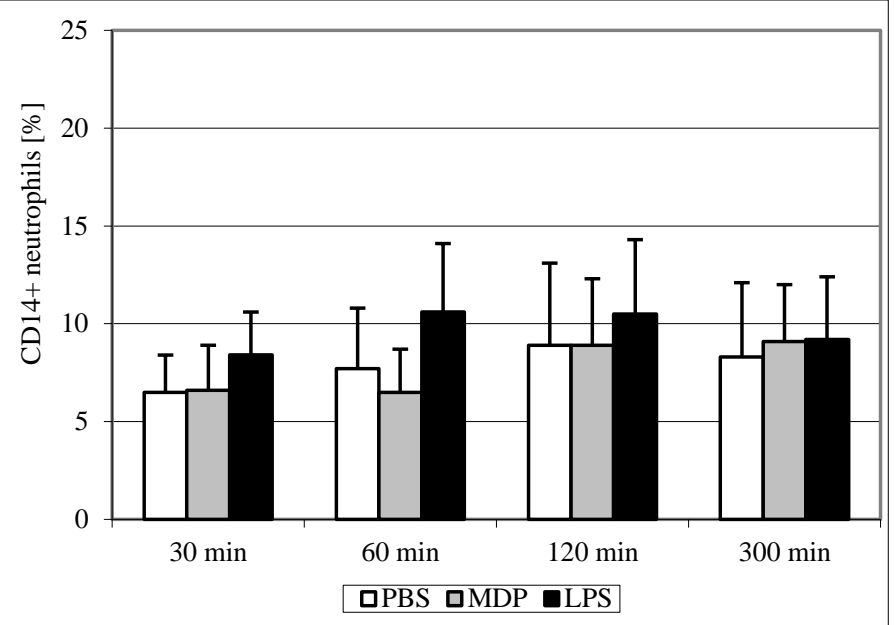

Figure 8 Proportion of CD14+ neutrophils MDP 20,0 $\mu \mathrm{g} \cdot \mathrm{ml}^{-1}$, LPS 2,0 $\mu \mathrm{g} \cdot \mathrm{ml}^{-1}$

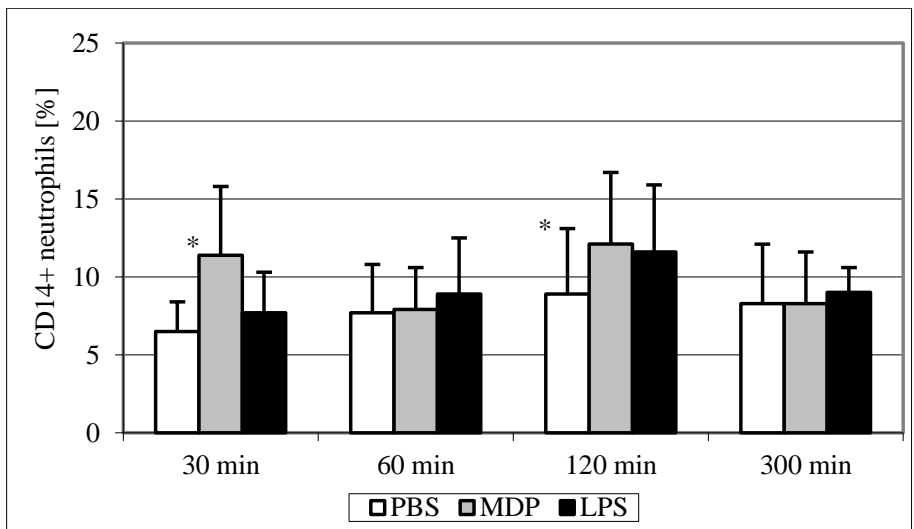

Figure 9 Proportion of CD14+ neutrophils MDP 200,0 $\mu \mathrm{g} \cdot \mathrm{ml}^{-1}$, LPS $20,0 \mu \mathrm{g} \cdot \mathrm{ml}^{-1}$

Figures 10, 11 and 12 show the percentages of CD44+ neutrophils during incubation of cell suspensions with PBS and different concentrations of MDP and LPS. Significantly higher percentages of CD44+ neutrophils were detected after $30 \mathrm{~min}$ incubation with LPS $(2.0 \mu \mathrm{g} / \mathrm{ml}, \mathrm{p}<0.05)$, after $30 \mathrm{~min}$ incubation with LPS $(20.0 \mu \mathrm{g} / \mathrm{ml}, \mathrm{p}<0.05)$, after 60 min incubation with LPS $(2.0 \mu \mathrm{g} / \mathrm{ml}$, $\mathrm{p}<0.001)$ and LPS $(20.0 \mu \mathrm{g} / \mathrm{ml}, \mathrm{p}<0.01)$ and also after $30 \mathrm{~min} .(\mathrm{p}<0.001)$ and $120 \mathrm{~min}(\mathrm{p}<0.05)$ incubations with MDP $(200.0 \mu \mathrm{g} / \mathrm{ml})$. 


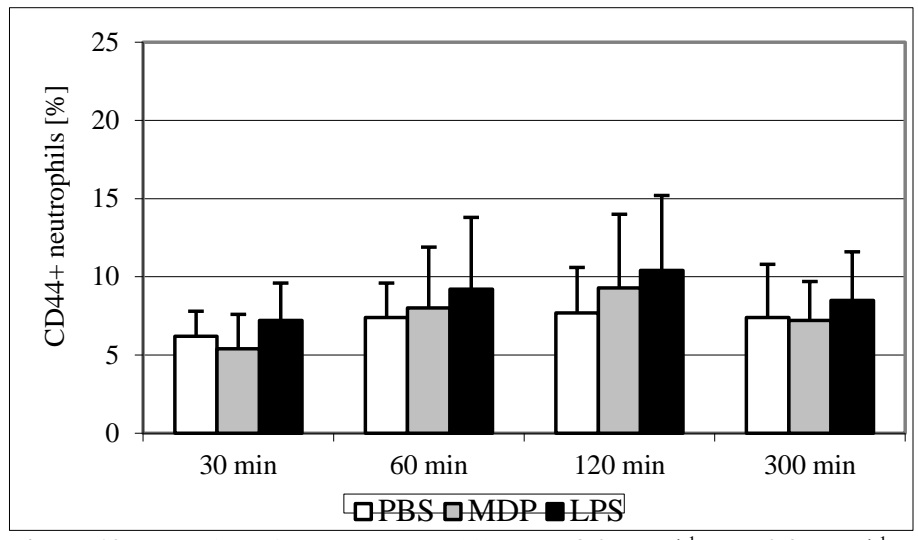

Figure 10 Proportion of CD44+ neutrophils MDP 2,0 $\mu \mathrm{g} \cdot \mathrm{ml}^{-1}$, LPS 0,2 $\mu \mathrm{g} \cdot \mathrm{ml}^{-1}$

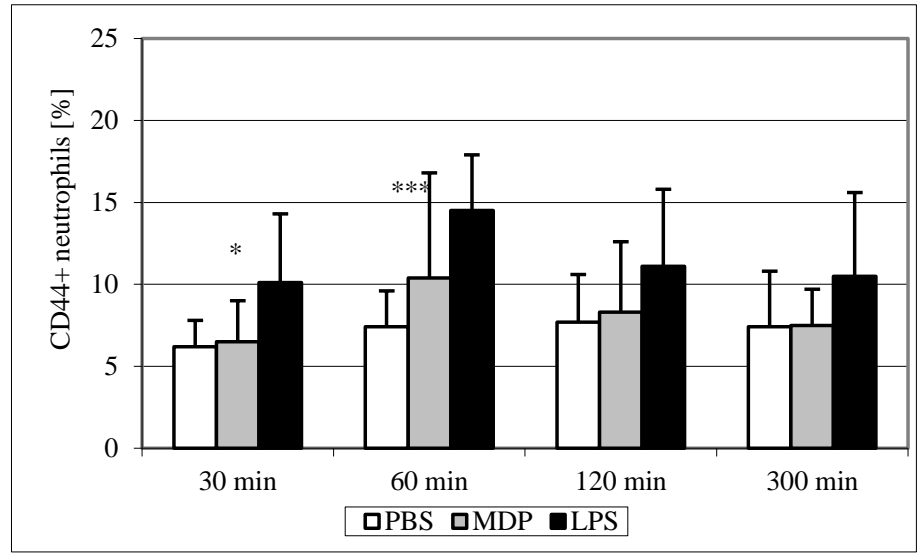

Figure 11 Proportion of CD44+ neutrophils MDP 20,0 $\mu \mathrm{g} \cdot \mathrm{ml}^{-1}$, LPS 2,0 $\mu \mathrm{g} \cdot \mathrm{ml}^{-1}$

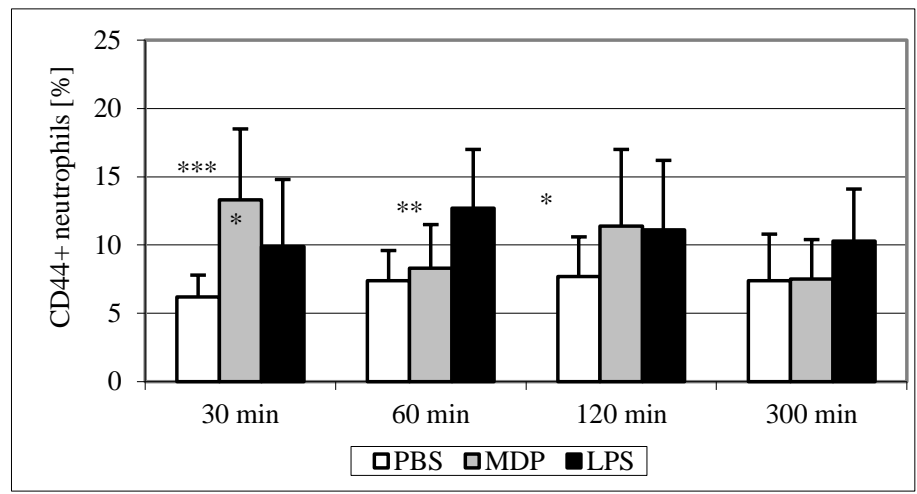

Figure 12 Proportion of CD44+ neutrophils MDP 200,0 $\mu \mathrm{g} \cdot \mathrm{ml}^{-1}$, LPS 20,0 $\mu \mathrm{g} . \mathrm{ml}$

\section{DISCUSSION AND CONCLUSION}

The purpose of the present study was to investigate the effects of MDP and LPS on CD14 and CD44 expression and lifespan by neutrophils. This study was performed under defined in vitro conditions, as it would not have been possible to detect the influence of the mammary gland tissue micro-environment on the biological characteristics of cells, or to eliminate its effect, had the experiments been performed under in situ conditions.

In order to conduct this experiment, it was necessary to obtain mammary gland neutrophils using of an inert agent, PBS. As the number of pathogens increases after colonisation, resulting in elevated production of toxins, the cell suspensions were incubated with three different concentrations of MDP and LPS so as to best mimic a natural infection of the mammary gland.

During incubation of the cell suspensions, the percentage of apoptotic neutrophils increased due to ageing (Sládek, Ryšánek, 2000). Their culture with MDP and LPS was characterised by a slower increase in apoptotic neutrophil percentages compared to PBS. As natural ageing and mortality occur during incubation of cells that have not been treated with a biological component, we found higher percentages of apoptotic neutrophils in PBS. This is in accordance with the results published by Colotta et al. (1992), Yamamoto et al. (1993), Haslett et al. (1995), Watson et al. (1997), Liu et al. (2005) and Ryšánek et al. (2005), who all documented inhibition of apoptosis by the aforementioned bacterial cell wall components. Whilst LPS causes a delay in apoptosis, opsonized or nonopsonized Escherichia coli bacteria induce apoptosis (Watson $\boldsymbol{e t}$ al., 1996; Colamussi $\boldsymbol{e}$ al., 1999). The effect of bacterial components on the delay in apoptosis, however, documented by significant differences in the percentages of apoptotic neutrophils between cell suspensions incubated with PBS and LPS, was detected in the present study only after a longer period of incubation (300 minutes). Comparable findings concerning blood neutrophils were reported by Payne et al. (1994) and Van Oostveldt et al. (2001), whereas Savill et al. (1989) observed lower percentages of apoptotic neutrophils from blood and neutrophils from articular inflammatory exudates. The differences in percentage of apoptotic neutrophils from peripheral blood and tissue during culture result from neutrophils rapidly losing their energy reserves after leaving the bloodstream (Naidu, Newbould, 1973), this being one reason for their decreased lifespan.

Evaluation of sources of variability indicated that time period played the most important role in increasing percentages of apoptotic neutrophils during incubation, with the bacterial component as the second most important factor. Concentrations of MDP and LPS did not appear to be sources of variability, as all three concentrations had the same effect on change in the percentage of apoptotic neutrophils.

It is noteworthy that in all cases higher percentages of apoptotic neutrophils were detected by FCM after Annexin V/PI staining than by SYTO 13 staining. This can be explained by the fact that Annexin V/PI stains neutrophils demonstrating early apoptotic changes, whilst SYTO 13 stains late apoptotic neutrophils (Martin et al., 1994; 1995; Zhang et al., 1997; Zhang, Xu, 2000).

The percentage of neutrophils with expressed CD14 receptors did not change markedly during culture in the medium with the lowest concentrations of MDP and LPS. The slight increase in percentage was not significant. Differences between the control cells and cells exposed to the bacterial cell wall components were not significant over all time periods.

The course of CD14 receptor expression by neutrophils was comparable during culture with the intermediate concentration of bacterial cell wall constituents in the medium. No significant differences in percentages of CD14+ neutrophils were observed between the control and neutrophils exposed to this concentration of MDP and LPS at different time periods. These concentrations of Grampositive and Gram-negative bacteria cell wall components did not modify the expression of CD14 receptors on neutrophils during incubation.

Different percentages of CD14+ neutrophils were detected during the culture of cell suspensions with the highest concentration of bacterial components. After a 30 minutes incubation of cells with MDP, the percentage of CD14 neutrophils was markedly higher compared to the non-treated suspensions, as well as to the percentage of CD14+ neutrophils exposed to LPS. This finding is surprising, as, in previous studies, LPS has been reported as having a high potential to modify some fundamental biological characteristics of neutrophils (Colotta et al., 1992, Yamamoto et al., 1993; Watson et al., 1997; Sladek et al., 2002). The percentage of CD14+ neutrophils in control samples was constant during the time of investigation. After incubating cells with MDP for 120 minutes, the percentage of CD14+ neutrophils was again highest.

Landmann et al. (1996) and Antal-Szalmas et al. (2000) referred to a decrease in CD14 expression by macrophages exposed to LPS. These authors described a reverse effect of LPS on cells of the defence system, with LPS inducing a decrease in CD14 expression due to protease-dependent cleavage and shedding of the CD14 cell membrane into the supernatant. Lin et al. (2004) confirmed that LPS induced this response. No similar decrease was observed, however, in neutrophils. No information concerning the influence of MDP on the decrease in percentage of CD14+ neutrophils or macrophages is available in the literature.

CD44 expression showed an increasing trend over a period of 120 minutes of incubation of cells with the lowest concentrations of bacterial components. This was followed by a decreased expression of CD44. No marked changes in CD44 expression were detected in non-treated cells.

An intermediate concentration of bacterial components in the medium induced an increase in the percentage of CD44+ neutrophils, especially after incubation with LPS. A significant increase in the percentage of CD44+ neutrophils was observed for a period of 60 minutes, with a subsequent decrease. A similar trend was observed when cells were incubated with MDP, though the differences were less marked. The percentage of non-treated CD44+ neutrophils remained constant during the investigation period. It is apparent that both bacterial components can modify the expression of CD44. As regards LPS, this is in accordance with the studies of Takazoe et al. (2000), Cairns et al. (2001) and Wang et al. (2002).

Cells cultured in the medium with the highest concentrations of MDP and LPS resulted in a significant increase in the number of CD44+ neutrophils. In MDP, this occurred after only 30 minutes of incubation. It follows from the present study that high concentrations of MDP (such as were used in this study) modify CD44 expression much more intensively than does LPS. This is somewhat surprising, as it is known that the sensitivity of neutrophils to MDP, and potentially to peptidoglycan, is much lower than it is to LPS (with sensitivity approximately just 1/1000 of that to LPS) (Gupta et al., 1996; Dziarski et al . 1998).

When compared with control, cells exposed to LPS expressed CD44 at a significantly greater level for a period of 60 minutes. No changes in CD44 expression occurred in this case as well as in the aforementioned cases. In the following time periods, decreasing expression of CD44 was observed. The activated cells are probably responding to LPS more slowly, resulting in a delay in attaining peak CD44+ neutrophil levels in comparison with MDP exposure. 
We have not found any mention of this fact, however, in the available literature. Due to the very similar effect of MDP and LPS on CD14 expression, comparable effects of these components on CD44 can also be expected.

A further focus of interest in the present study was the percentage of apoptotic CD14+ and CD44+ neutrophils during in vitro culture. Provided CD14 and CD44 play a role in the "eat me" signals for recognition of apoptotic neutrophils by macrophages, positive correlations should exist between their percentages. This association was not confirmed, however, in the present in vitro study. This conclusion may not be so surprising, however, as neutrophils present in the duct system of the mammary gland are affected by a series of factors in addition to LPS and MDP (Paape et al., 2003).

Acknowledgments: The authors wish to express their thanks for financial support to the projects of IGA AF MENDELU No. AF-IGA-2018-tym002.

\section{REFERENCES}

Akgul, C., Moulding, D.A. \& Edwards, S.W. (2001). Molecular control of neutrophil apoptosis. FEBS Letters 487, 318-322. https://doi.org/10.1016/s00145793(00)02324-3

Antal-Szalmas, P., Poppelier, M.J.J.G. \& Broekhuizen, R. (2000). Diverging pathways for lipopolysaccharide and CD14 in human monocytes. Cytometry 41, 279-88. https://doi.org/10.1002/1097-0320(20001201)41:4<279::aidcyto6>3.3.co; $2-2$

Cairns, A.P., Crockard, A.D. \& Bell, A.I. (2001). Leukocyte complement receptor expression in systemic lupus erythematosus in relation to apoptotic cell clearance. Arthritis and rheumatism 44, 274.

Colamussi, M.L., White, M.R., Crouch, E. \& Hartshom, K.L. (1999). Influenza A virus accelerates neutrophil apoptosis and markedly potentiates apoptotic effects of bacteria. Blood 93, 2395-403.

Colotta, F., R, F., Polentarutti, N., Sozzani, S. \& Mantovani, A. (1992) Modulation of granulocyte survival and programmed cell death by cytokinines and bacterial products. Blood, 80, 2012-20.

Dosogne, H., Vangroenweghe, F., Mahrzad, J., Massart-Leën, A.M. \& Burvenich, C. (2003). Differential leukocyte count method for bovine low somatic cell count milk. Journal of Dairy Science, 86, 828-834 https://doi.org/10.3168/jds.s0022-0302(03)73665-0

Dziarski, R., Tapping, R.I. \&Tobias, P.S. (1998). Binding of bacteria peptidoglycan to CD14. Journal of biological chemistry 273, 8680-90. https://doi.org/10.1074/jbc.273.15.8680

Fadok, V.A., De Cathelineau, A., Daleke, D.L., Henson, P.M. \& Bratton, D.L. (2001). Loss of phospholipid asymmetry and surface exposure of phosphatidylserine is required for phagocytosis of apoptotic cells by macrophages and fibroblasts. J Biol Chem._12;276(2):1071-7. http://dx.doi.org/10.1074/jbc.M003649200

Gregory, Ch.D. \& Devitt, A. (2004). The macrophage and the apoptotic cell: an innate immune interaction viewed simplistically? Immunology. 113(1): 1-14 http://dx.doi.org/10.1111/j.1365-2567.2004.01959.x

Gupta, D., Kirkland, T.N., Viriyakosol, S. \& Dziarski, R. (1996). CD14 is a cellactivating receptor for bacterial peptidoglycan. Journal of biological chemistry 271, 23310-6. https://doi.org/10.1074/jbc.271.38.23310

Haslett, G., Savill, J.S., Whyte, M.K.B., Stern, M., Dransfield, I. \& Meagher, L.C. (1995). Granulocyte apoptosis and the control of inflammation. Philosophical Transactions of the Royal Society of London, 345, 327-33. https://doi.org/10.1007/978-94-011-0553-8_15

Jacobs, L., Nawrot, T.S., De Geus, B., Meeusen, R., Degraeuwe, B., Bernard, A., Sughis, M., Nemery, B. \& Panis, L.I. (2010). Subclinical responses in healthy cyclists briefly exposed to traffic-related air pollution: an intervention study. Environmental Health. 9 (64), 64. http://dx.doi.org/ 10.1186/1476-069X-9-

Kagan, V.E., Gleiss, B. Tyurina, Y.Y., Tyurin, V.A., Elenström-Magnusson, C., Liu, S.X., Serinkan, F.B., Arroyo, A., Chandra, J., Orrenius, S. \& Fadeel, B (2002). A role for oxidative stress in apoptosis: oxidation and externalization of phosphatidylserine is required for macrophage clearance of cells undergoing Fas$\begin{array}{llll}\text { mediated } & \text { apoptosis. } & J & \text { Immunol. }\end{array}$ https://doi.org/10.4049/jimmunol.169.1.487

Khan, A.I., Kerfoot, S.M., Heit, B., Liu, L., Andonegui, G., Ruffell, B., Johnson, P. \& Kubes, P. (2004). Role of CD44 and Hyaluronan in Neutrophil Recruitment The Journal of Immunology 173, 7594-7601. https://doi.org/10.4049/jimmunol.173.12.7594

Kitchens, R.L. (2000). Role of CD14 in cellular recognition of bacterial lipopolysaccharides. Chemical Immunology. 74, 61-82. ISBN 3-8055-69173. https://doi.org/10.1159/000058750

Landmann, R., Knopf, H.P., Link, S., Sansano, S., Schumann, R. \& Zimmerli, W. (1996). Human monocyte CD14 is upregulated by lipopolysaccharide. Infection and immunity 64, 1762-9. https://doi.org/10.1016/j.matbio.2018.05.007

Lakshmanan, I. \& Batra, S. K. (2013). Protocol for Apoptosis Assay by Flow Cytometry Using Annexin V Staining Method. Bio-protocol 3 (6): e374. https://doi.org/10.21769/BioProtoc.374
Lin, S.M., Frevert, C.W., Kajikawa, O., Wurfel, M.M., Ballman, K., Mongovin, S., Wong, V.A., Selk, A. \& Mertin, T.R. (2004). Differencial regulation of membrane CD14 expression and endotoxin-tolerance in alveolar macrophages. American journal of respiratory cell and molecular biology 31, 162 70. https://doi.org/10.1165/rcmb.2003-0307oc

Liu, J.J., Song, C.W., Yue, Y., Duan, C.G., Yang, J., He, T. \& He, Y.Z. (2005) Quercetin inhibits LPS-induced delay in spontaneous apoptosis and activation of neutrophils. Inflammation Research 54, 500-7. https://doi.org/10.1007/s00011005-1385-2

Martin, S.J., Green, D.R. \& Cotter, T.G. (1994). Dicing with death: dissecting the components of the apoptotic machinery. Trends in biochemical sciences 19, 26 30. https://doi.org/10.1016/0968-0004(94)90170-8

Martin, S.J., Reutelingsperger, C.P., Mcgahon, A.J., Radar, A., Van-Schie, R.C., Laface, D.M. \& Green, D.R. (1995). Early distribution of plasma membrane phosphatidylserine is a general feature of apoptosis regardless of the initiating stimulus: inhibition by overexpression of $\mathrm{Bcl}-2$ and Abl. Journal of Experimental Medicine 182, 1545-56. https://doi.org/10.1084/jem.182.5.1545

Maskrey, B.H., Megson, I.L., Whitfield, P.D. \& Rossi, A.G. (2011). Mechanisms of Resolution of Inflammation. Thrombosis, and Vascular Biology 31, 10011006. https://doi.org/10.1161/ATVBAHA.110.213850

Naidu, T.G. \& Newbould, F.H. (1973). Glycogen in leukocytes from bovine blood and milk. Canadian journal of comparative medicine 37, 47-55.

Nathan, C. (2002). Points of control in inflammation._Nature, 19-26;420(6917), 846-52. Review. https://doi.org/10.1038/nature01320

Neumann, J., Ziegler, K., Gelleri, M.,Frohlich-Nowoisky, J., Liu, F.B. Bettinghausen, I.,Schuppan, D., Birk, U.,Poschl, U. \& Cremer, C. (2019) Nanoscale distribution of TLR4 on primary human macrophages stimulated with $\begin{array}{llll}\text { LPS and } & \text { ATI. NANOSCALE } & \text { 11, } & \text { 9769-9779. }\end{array}$ http://dx.doi.org./10.1039/c9nr00943d

Paape, M.J., Lilius, E.M., Wiitanen, P.A., Kontio, M.P. \& Miller, R.H. (1996) Intramammary defense against infections induced by Escherichia coli in cows American journal of veterinary research $57,477-82$.

Paape, M.J., Bannermann, D.D., Zhao, X. \& Lee, J.W. (2003). The bovine neutrophils: Structure and function in blood and milk. Veterinary research 34 597-627. https://doi.org/10.1051/vetres:2003024

Payne, C.L., Glasser, L., Tischler, M.E., Wyckoff, D., Cromey, D., Fiederlein, R. \& Bohnert, O. (1994). Programmed cell death of the normal human neutrophil An in vitro model of senescence. Microscopy research and technique 28, 327-44. https://doi.org/10.1002/jemt.1070280408

Ranoa, D.R., Kelley, S.L. \& Tapping, R.I. (2013). Human lipopolysaccharidebinding protein (LBP) and CD14 independently deliver triacylated lipoproteins to Toll-like receptor 1 (TLR1) and TLR2 and enhance formation of the ternary signaling complex. The Journal of Biological Chemistry, 288 (14), 972941. https://doi.org/10.1074/jbc.M113.453266

Ryšánek, D., Babák, V., Sládek, Z. \& Toman, M. (2001). Variations among unbred heifers in the activities of polymorphonuclear leucocytes from the mammary gland and blood. Journal of veterinary medicine, Series B, 48, 31-41. https://doi.org/10.1046/j.1439-0450.2001.00423.x

Ryšánek, D., Sládek, Z., Vašíčková, D. \& Faldyna, M. (2005). Effects of Certain Inducers of Leukocytes Migration into the Bovine Mammary Gland on Neutrophil Apoptosis Manifestation in a Subsequent in Vitro Cultivation Physiological research 54, 305-12.

Savill, J.S., Wyllie, A.H., Henson, J.E., Walport, M.J., Henson, P.M. \& Haslett, C. (1989). Macrophage phagocytosis of aging neutrophils in inflammation. Programmed cell death in the neutrophil leads to its recognition by macrophages. The Journal of clinical investigation, 83, 865-75. https://doi.org/10.1172/JCI113970

Savill, J.S., Fadok, V., Henson, P. \& Haslett, C. (1993). Phagocyte recognition of cells undergoing apoptosis. Immunology Today 14, 131-136. https://doi.org/10.1016/0167-5699(93)90215-7

Sládek, Z. \& Ryšánek, D. (2000). Apoptosis of polymorphonuclear leukocytes of the juvenile bovine mammary gland during induced influx. Veterinary research 31, 553-63. https://doi.org/10.1051/vetres:2000139

Sládek, Z., Ryšánek, D. \& Faldyna, M. (2002). Activation of phagocytes during initiation and resolution of mammary gland injury induced by lipopolysaccharide in heifers. Veterinary research 33, 191-204. https://doi.org/10.1051/vetres:2002007

Sládek, Z. \& Ryšánek, D. (2006). The role of CD14 during resolution of experimentally induced Staphylococcus aureus and Streptococcus uberis mastitis. Comparative Immunology, Microbiology and Infectious Diseases, 29, 243-262. https://doi.org/10.1016/j.cimid.2006.06.006

Takazoe, K., Tesch, G.H. \& Hill, P.A. (2000). CD44-mediated neutrophil apoptosis in the rat. Kidney international 58, 1920-30. https://doi.org/10.1046/j.1523-1755.2000.00364.x

Takeuchi, O., Hoshino, K., Kawai, T., Sanjo, H., Takada, H., Ogawa, T., Takada, K. \& Akira, S. (1999). Differential roles of TLR2 and TLR4 in recognition of Gram-negative and Gram-positive bacterial cell wall components. Immunity 11, 443-451. https://doi.org/10.1016/s1074-7613(00)80119-3

Takeuchi, O., Hoshino, K. \& Akira, S. (2000). Cutting edge: TLR2-deficient and MyD88-deficient mice are highly susceptible to Staphylococcus aureus infection. 
Journal of $\quad$ Immunology $\quad 165, \quad 5392-5396$.

https://doi.org/10.4049/jimmunol.165.10.5392

Tapping, R.I. \& Tobias, P.S. (2000). Soluble CD14-mediated cellular responses to lipopolysaccharide. Chemical Immunology. 74, 108-21. ISBN 3-8055-69173. https://doi.org/10.1159/000058751

Teder, P., Vandivier, R.W., Jiang, D., Liang, J., Cohn, L., Pure, E., Henson, P.M. \& Noble, P.W. (2002). Resolution of lung inflammation by CD44. Science 296 (5565), 155-158. https://doi.org/10.1126/science.1069659

Trotter, J. (2000). WinMDI 2.8 software. Windows Multiple Document Interface Flow Cytometry Application.

Vachon, E., Martin, R., Plumb, J., Kwok, V., Vandivier, R.W., Glogauer, M., Kapus, A., Wang, X., Chow, C.W., Grinstein, S. \& Downey, G.P. (2006). CD44 is a phagocytic receptor. Blood, 107(10), 4149-4158. https://doi.org/10.1182/blood-2005-09-3808

Van Oostveldt, K., Vangroenweghe, F. \& Dosogne, H. (2001). Apoptosis and necrosis of blood and milk polymorphonuclear leukocytes in early and midlactating healthy cows. Veterinary research 32, 617-22. https://doi.org/10.1051/vetres:2001143

Vermes, I., Haanen, C., Stefferns-Naaken, H. \& Reutelingsperger, C.P. (1995). A novel assay for apoptosis: flow cytometry detection of phosphatidylserine expression on early apoptotic cells using fluorescein labelled Annexin V. Journal of Immunology 184, 39-51. https://doi.org/10.1016/0022-1759(95)00072-i

Vivers, S., Dransfield, I. \& Hart, S.P. (2002). Role of macrophage CD44 in the disposal of inflammatory cell corpses. Clinical Science 103, 441-449. https://doi.org/10.1042/cs1030441

Watson, R.W.G., Redmont, H.P., Wang, J.H., Condron, C. \& Bouchier-Hayes, D. (1996). Neutrophil undergo apoptosis following ingestion of Escherichia coli. Journal of Immunology 156, 3986-92.

Watson, R.W.G., Rottstein, O.D., Nathens, A.B., Pardo, J. \& Marshall, J.C. (1997). Neutrophil apoptosis is modulated by endothelial transmigration and adhesion molecule engagement. Journal of Immunology 158, 945-53.

Wang, Q., Teder, P., Judd, N.P., Noble, P.W. \& Doerschuk, C.M. (2002). CD44 deficiency leads to enhanced neutrophil migration and lung injury in Escherichia coli pneumonia in mice. The American journal of pathology 161, 2219-28. https://doi.org/10.1016/s0002-9440(10)64498-7

Yamamoto, C.H., Yoshida, S.I., Taniguchi, H., Qin, M.H., Maymoto, H. \& Mizuguchi, Y. (1993). Lipopolysaccharide and granulocyte colony-stimulating factor delay neutrophil apoptosis and ingestion by guinea pig macrophages. Infection and immunity, 61, 1972-9.

Yoo, S.K., Starnes, T.W., Deng, Q. \& Huttenlocher, A. (2011). Lyn is a redox sensor that mediates leukocyte wound attraction in vivo. Nature 480 (7375), 10912. https://doi.org/10.1038/nature10632

Zhang, G., Gurtu, V., Kain, S.R. \& Yan, G. (1997). Early detection of apoptosis using a fluorescent conjugate of annexin V. BioTechniques 23, 525-31. https://doi.org/10.2144/97233pf01

Zhang, J.H. \& Xu, M. (2000). DNA fragmentation in apoptosis. Cell research 10, 205-11. https://doi.org/10.1038/sj.cr.7290049 